\title{
An Analysis of NEETs Situation in UE-28 Countries and the Example of Netherlands
}

\begin{abstract}
The aim of the article is to compare a NEET rate in EU-28 countries based on the most recent Eurostat statistical studies, and to solve a research problem concerning the situation of youth on the job market through answering a research question how did the NEETs situation change in the period under question which is 2008-2018. An increase of the negative trend of high unemployment among young people is constant, therefore it seems justified for the analysis to cover the period of ten years, which assumingly allows for the more complex assessment of the investigated issue. The analysis is supplemented by the case study of Netherlands which has the lowest NEET rate and as such stands as the example for the other European countries to follow.
\end{abstract}

Key words: NEETs generation, youth unemployment, unemployment in the European Union, NEETs in the Netherlands, supporting youth on the labor market

\section{Introduction}

Q uestions about the future of the European Union are increasingly more often asked in national and international public debates. Problems started in 2008 when the EU experienced the severe economic crisis. ${ }^{1}$ Particularly then, there could have been observed the first symptoms of the erosion of solidarity principle shared by the community. Conflicts and questions showed up about reasons why rich countries should help the weaker members of the community. Another significant challenge was the European migrant crisis which also divided the European Union. The last act of troubles was the so-called Brexit ${ }^{2}$ which resulted in abandoning the EU by one of its member states (the Great Britain which was the EU member since 1973).

Despite problems discussed by the most important European media, the European Union also faces challenges concerning particular social groups. One of such issues is

${ }^{1}$ In the body of literature there can be found two dates of the crisis beginning - 2007 and 2008. This article supports the latter one, more precisely September 15, 2008 when the investment bank Lehman Brothers declared bankruptcy.

${ }^{2}$ In June 2016 in the United Kingdom there was a referendum in which the UK citizens decided whether to continue or reject the EU membership. 51,9\% of them voted for leaving the EU. The process lasted longer than expected and caused numerous social conflicts concerning the Brexit withdrawal agreement and the future of the state borders. The situation has caused tensions in the whole European Union. Eventually, the UK left the EU in January 31, 2020. 
the problem of unemployment in the EU countries, particularly among young citizens. This phenomenon is analyzed mostly from the perspective of demographic properties such as gender, age, nationality or place of residence. It should be the most important matter for the future of the EU, especially for its economy, mainly because it is not an accidental case, but a worsening trend since 2008 .

In time it turned out that the issue is much more sophisticated than assumed, because among the group of unemployed young people there is a separate group not interested in life and career development. NEETs (Neither in Employment nor in Education and Training) is the name given to the generation of young people professionally inactive, staying beyond the education system and the market.

The aim of the article is to compare a NEET rate in EU-28 countries based on the most recent Eurostat statistical studies, and to solve a research problem concerning the situation of youth on the job market through answering a research question how did the NEETs situation change in the period under question which is 2008-2018. An increase of the negative trend of high unemployment among young people is constant, therefore it seems justified for the analysis to cover the period of ten years, which assumingly allows for the more complex assessment of the investigated issue. The analysis is supplemented by the case study of Netherlands which has the lowest NEET rate and as such stands as the example for the other European countries to follow.

\section{NEET Generation - Characteristics}

The term NEET was coined in 1980s in the United Kingdom, but in official documents it was used for the first time in $1999^{3}$ (Skórska, 2016, p. 154) to describe persons mostly exposed to educational and professional inactivity. Comparing with other names of that social group that can be found in the body of literature, the term NEETs seems to be the most neutral ${ }^{4}$ which is why it was quickly adopted beyond the United Kingdom. Later on, it has been used by all EU countries, while other states, such as Japan, New Zealand or Hong Kong, elaborated their own, separate definitions (European Foundation, 2012, p. 20).

NEET is a shortcut for Neither in Employment nor in Education and Training. In the EU, its official definition may be found in the Regulation (EU) No. 1304/2013 of the European Parliament and of the Council of 17 December 2013 on the European Social Fund and Repealing Council Regulation (EC) No. 1081/2006. The same document indicates three criteria qualifying young people as NEETs. These are the people who:

- do not work - are unemployed or professionally passive;

- do not learn - do not participate in formal education;

- do not participate in workshops increasing personal competences.

Therefore, it can be assumed that persons meeting the criteria of belonging to the NEET generation are fully withdrawn from the job market and many other social activi-

3 The document's name is Bridging the Gap: New Opportunities for 16-18 Year Olds Not in Education, Employment or Training (1999), Presented to Parliament by the Prime Minister by Command of Her Majesty July 1999.

${ }^{4}$ The equivalent of NEET that may be encountered is: going to nowhere; generation X; unregistered; omitted by statistics; lost youth; fading away youth. 
ties (which may be associated with the lack of income, limited social contacts naturally present in a workplace or education unit, etc.). ${ }^{5}$

Countries mostly agree on the same NEET definition although they put emphasis on slightly different accents. A bigger problem is defining the age of people belonging to the generation. The majority of European countries addressing the problem adopts age range 15-24, yet in e.g. Japan the range is wider (15-34) and the workshops criterion was replaced by the assumption that the NEETs are people who do not clean their houses (OECD, 2009, p. 45). South Korea adopted the same age range as Japan, but, once again, the criteria are different: as NEETs are considered people who do not have family obligations (do not have children and are unmarried) and do not go to a private or public school preparing for work (OECD, 2007, p. 39). Such discrepancies eventually cause that there is no one, universal definition, and different NEETs age ranges cause that international comparisons are very difficult. However, international organizations such as OECD, European Commission or the Council of Europe decided to create a unitary methodology which allows for conducting a proper comparative analysis of NEET indicator in the majority of countries across the world.

It is worth to underline that the basic difference between youth unemployment and NEET rate is that NEET considers also the category of young people who are professionally passive. That is why the indicator percentage values always is lower that the youth unemployment rate, despite the fact that in terms of absolute value the NEET population is bigger than the unemployed youth (European Court of Auditors, 2018, p. 26).

\section{Illustration 1. Youth unemployment rate vs NEET rate}

\section{Youth unemployed rate:}

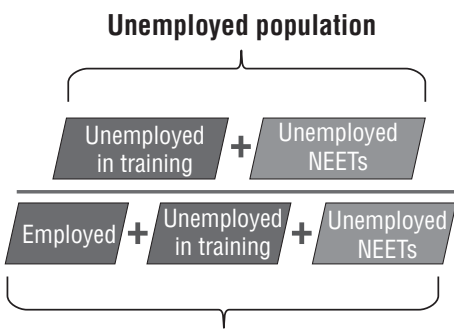

Active youth population
NEET rate:

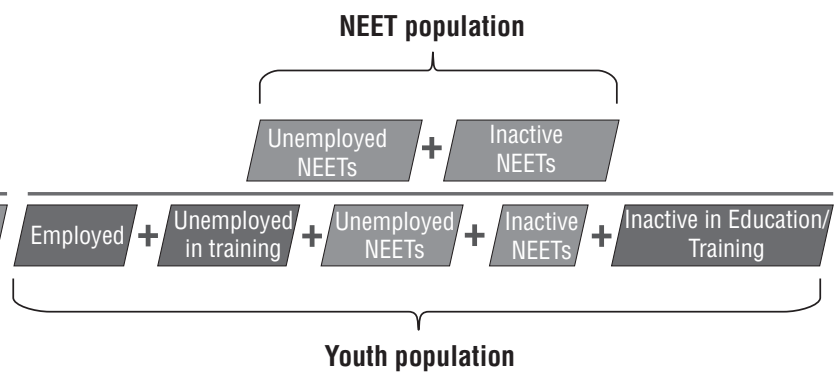

Source: European Court of Auditors, Audit Compendium. Youth unemployment and the integration of young people into the labour market, p. 27.

Since 2010 the concept of NEET is applied by EU institutions as an indicator shaping directions of policies oriented on youth employment, training and education in EU-28 countries. For the first time, it was addressed during the debate on the programme

${ }^{5}$ Research shows that despite people belonging to NEET have more free time, because of the lack of job or participation in training and courses, they do not use it as their peers. It means that NEETs less frequently enjoy culture (e.g. go to the cinema, theater, concerts or exhibitions), read books and participate in activities for the society (e.g. participation in organizations, political parties, associations) (Tomczyk, Maćkowicz, Wyżga, Curyło, Pietryga-Szkarłat, Mróz, 2018, p. 137). 
"Europe 2020," precisely "Youth on the Move" initiative. Initially, within the initiative a narrower group was considered (15-24) but eventually age range was extended (15-29). Moreover, in 2013 the European Commission referred to the European Council a submission concerning guarantees for youth in the EU member states. The guarantees were to assure young people good employment, education or internship offers in the period of four months from the moment of losing job or finishing a formal education. In 2016 the European Commission elaborated another initiative "Investing in Europe's youth" supporting activities which favor young people.

The European Union realizes the problem's significance and undertakes numerous initiatives fostering youth at the job market. An additional stimulus is a fact that initiatives that have been implemented so far bring desired results. That is why the financial support for activities promoting youth employment is maintained and extended.

\section{The Analysis of NEETs Situation in EU-28 Countries in 2008-2018}

2008 was a turning point for the world economy because of the global economic crisis which has impacted nearly all countries on the planet. It has also affected the situation of young people (15-24, accordingly with the age range adopted by the EU) on the job market. That is why it is the subject of analysis in this paper in 2008-2018. All data used in the study were elaborated based on information available in the database of European Statistical Office - Eurostat.

The latest available Eurostat statistical data concerning NEET comes from 2018, more precisely from its third quarter. In that period there was $10,6 \%$ of unemployed, uneducated and untrained people. Chart 1 presents the number of people classified as NEETs in particular quarter of 2008-2018.

Chart 1. Unemployed, uneducated and untrained young people in EU-28 countries in 2008-2018 (\%)

15

10

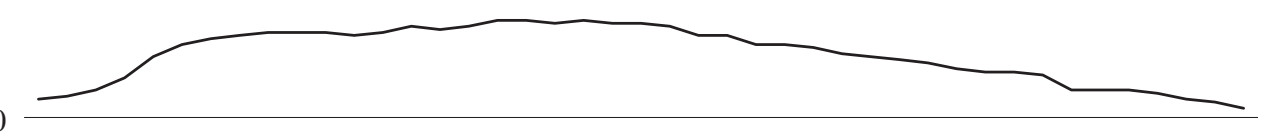

5

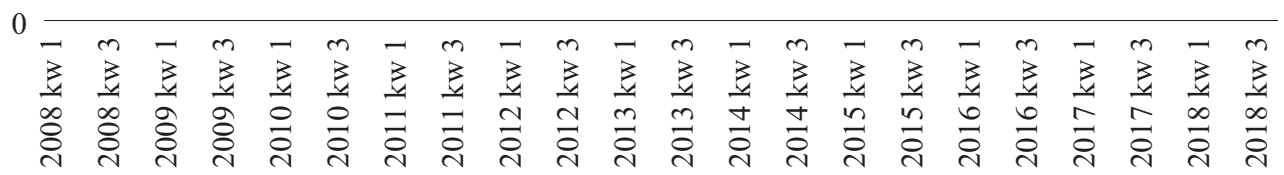

Source: Own study based on Eurostat data, http://appsso.eurostat.ec.europa.eu/nui/submitViewTableAction. do, 04.04.2019. 
During the analyzed period the highest NEET rate was in 2012, in its $1^{\text {st }}, 2^{\text {nd }}$ and $4^{\text {th }}$ quarter: $13,2 \%$. In the $3^{\text {rd }}$ quarter it slightly dropped to $13,1 \%$ but in the $4^{\text {th }}$ came back to its initial value. The lowest NEET rate was in the $3^{\text {rd }}$ quarter of $2018: 10,3 \%$. The biggest change occurred at the very beginning of 2009 when the rate started growing, and eventually maintained the value of $12-13 \%$ up until $3^{\text {rd }}$ quarter of 2013 . Analyzing data from the earlier period, it can be observed that until 2000 NEET rate systematically dropped until 2008. Currently, the situation of NEETs on the job market begins to stabilize because the rate has pre-crisis values, about $10 \%$. It is worth noting that because of the crisis 2008 caused not only the increase of the number of NEETs but also the overall unemployment in the whole European Union which the highest rate was noted in 2013 - 10,9\% (Eurostat Statistical Books, 2015, p. 34). The economic recession caused that youth experienced the crisis outcomes the most. Also, it is important to underline the fact that the gender gap decreased in terms of unemployment. For NEETs the situation looked similar - gender gap decreased.

Analyzing the change of NEET rate over years, there should be noted various determinants that shape it. Certainly, the most important one is its level in particular EU-28 countries. Chart 2 presents NEET rate in EU-28 countries in two moments important for the analysis. First is the mentioned 2008 as a year in which the economic crisis started and second is 2018 because this is a year when the recent data was published.

Chart 2. NEET rate in EU-28 countries in 2008-2018 (\%)

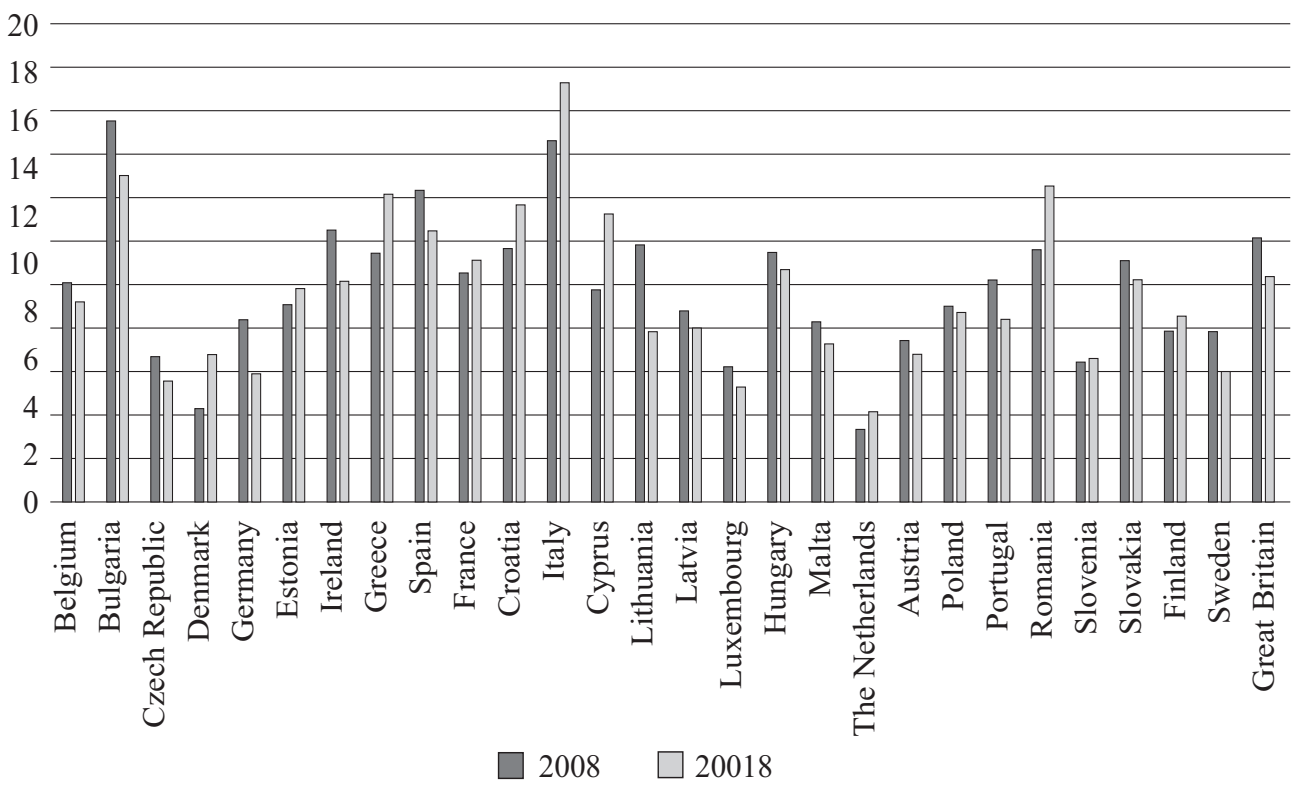

Source: Own study based on Eurostat data, http://appsso.eurostat.ec.europa.eu/nui/show.do?dataset=1fsi_ neet_a\&lang=en, 04.04.2019.

The analysis of data consisted in the Chart 2 shows significant disproportions between EU countries in respect to the number of unemployed, uneducated and untrained youth. In the analyzed period the highest NEET rate was observable in Bulgaria $(17,4 \%$ 
in 2008 and $15,0 \%$ and 2018 ) and Italy (16,6\% in 2008 and even $19,2 \%$ in 2018). The lowest NEET rate was in Denmark (4,3\% in 2008 and 6,8\% in 2018) and Netherlands ( $3,4 \%$ in 2008 and $4,2 \%$ in 2018). It is worth to pay attention to the fact that in some countries the situation was opposite than in the majority of states in the analyzed period, particularly their NEET rate in 2018 was higher than in critical 2008. These are: Denmark $(4,3 \% ; 6,8 \%)$, Estonia (small difference $9,1 \% ; 9,8 \%)$, Greece $(11,4 \% ; 14,1 \%)$, France $(10,5 \% ; 11,1 \%)$, Croatia $(11,6 \% ; 13,6 \%)$, Italy $(16,6 \% ; 19,2 \%)$, Cyprus $(9,7 \%$; $13,2 \%)$ and Romania $(11,6 \% ; 14,5 \%)$. The biggest progress in terms of decreasing NEET rate was noted in Lithuania (4\% drop), Germany (2,5\% drop) and Ireland (2,6\% drop). However, the unemployment rate among young people in Lithuania and Ireland is still very high. It can be stated that in countries with low NEET rate there is generally high keenness for employment, and effective education and training system supporting the decrease of structural mismatch. Additionally, there is a well-coordinated procedure of passing from the educational system to the job market.

\section{Illustration 2. NEET \% rate in 2018 (regions according to NUTS 2)}

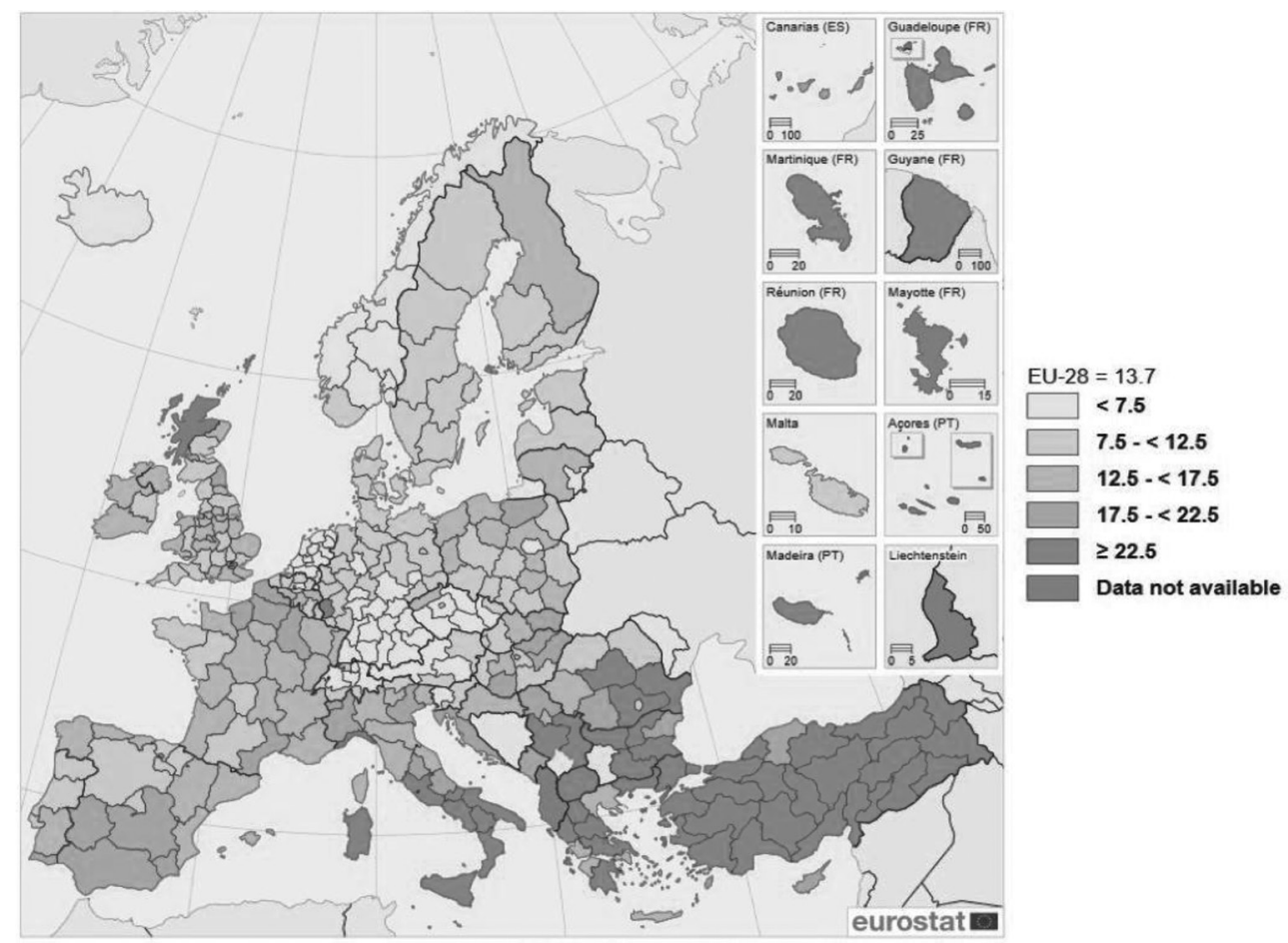

Source: Eurostat regional yearbook 2019 edition, 2019, p. 68.

In 2018 the lowest NEET rate (marked with the brightest color) was in the Czech Republic, Germany and Netherlands. In total, there were 42 regions in the EU in which NEET rate was beneath $7,5 \%$, including:

- all 12 regions of Netherlands,

- 6 of 8 regions in the Czech Republic, 
- 16 German regions.

The highest NEET rate was noted in two most distanced regions of France $-41,2 \%$ and $46,6 \%$.

\section{Netherlands - An Example to Follow?}

Based on the presented Eurostat data it results that in 2018 the lowest NEET rate was in Netherlands $(4,2 \%)$. The second and third place was taken by Luxemburg $(5,3 \%)$ and the Czech Republic (5,6\%). Interestingly, in Netherlands which has had the first place also ten years earlier, NEET rate increased of $0,8 \%$, while Luxemburg and the Czech Republic noted the desired drops $-0,9 \%$ and $1,1 \%$, respectively. Netherlands was selected for analysis because of maintaining the leading position for many years despite having worsening NEET rate. ${ }^{6}$

According to the analysists from the European Foundation for the Improvement of Living and Working Conditions (Eurofound), Netherlands belongs to the group of neoliberal countries, characterized with the dual system of education ${ }^{7}$ and flexicurity policies. ${ }^{8}$ In the group Netherlands is accompanied by Austria, Denmark, Finland, Germany, Luxemburg, Sweden and the United Kingdom. Except the UK, all these countries are characterized by the low NEET rate. Additionally, in their group the rate of unemployed and uneducated women is lower that the European average. Interestingly, in almost all of these countries the majority of NEETs is professionally inactive yet at the same time is has previous professional experience, and the rate of discouraged employees is much beneath the European average. The mentioned states, including the analyzed Netherlands, are characterized by the higher than the European average rate of NEETs with low level of education while the percentage of people with higher education is much beneath the EU average. It means that the typical (for this group) representative of NEETs has a lower level of education and has withdrawn from the job market and education system. Moreover, the low number of discouraged employees may mean that in the majority of

${ }^{6}$ The Institute for Public Policy Research based its recommendations for the British authorities on the solutions implemented in Netherlands. Its analysts paid a special attention to the present in Netherlands separate and pointed only to youth systems of state care (with special benefits), time limits for receiving unemployment benefits, programmes directing inactive young people back to the school or trainings, systems preventing the premature ending of education, and strong decentralization of all activities undertaken by state institutions. Additionally, the Dutch system of professional education based on the constant cooperation between companies and commonly available internships gained the analysts' recognition (Institute for Public Policy Research, 2013, p. 28).

7 System in which next to the traditional education in a vocational school, students are obligated by the practical learning of profession in a company (or workshops given by commerce guilds and chambers).

${ }^{8}$ Flexicurity is a concept that merges two terms: the flexibility and security of workers and entrepreneurships. According to Radosław Pyrek (2012, p. 127) "the task of flexicurity policy is to ensure the citizens of the member states the high level of employment protection, the possibility of free and easy finding a job independently on age and perspectives of professional development in constantly changing economic environment. Such a system supports the optimal use of possibilities created by globalization, and the flexicurity policy aims to create a system in which professional flexibility and social protection support each other". 
cases the decision about resigning from work and education could be made willingly and result from, e.g. family obligations or alternative way of career. Certainly, it is not a symptom of the presence of structural barriers in these countries for people entering the job market (Europejska Fundacja na rzecz Poprawy Warunków Życia i Pracy, 2012, pp. 38-39).

Despite the low NEET rate Netherlands is also characterized by one of the lowest unemployment rates among young people ( $7 \%$ in 2018, while the European average was $15,2 \%$ ) (Netherlands: Youth unemployment, Youth unemployment rate). It results from the systemic actions of the state making entering the job market by youth that have been undertaken for many years. These solutions are implemented by Dutch ministries: of education, culture, science, social affairs and foreign affairs in cooperation with communes, employers, unions and education institutes. They have to main goals: to decrease the number of persons prematurely ending education and to make entering the job market easier for young people through strengthening associations between the job market and education system. They are realized by, e.g. improving the availability of trainings organized in workplaces (professional trainings, internships) and creating incentives for employers to increase the number of job positions for youth (European Commission, 2020, p. 7). An interesting solution introduced by Amsterdam authorities is the use of gamification as an innovative way of fighting against unemployment among young people. The programme participants were proposed e.g. a game Ready4Work020 in which it was possible to train competences useful during job interviews and meetings with employers. The offer included also trainings for future programists in the scope of making applications (within The App Academy) (Amsterdam uses gamification). Such nonstandard methods are a very good way to approach the young generation, particularly those who spend the huge part of their lives in cyberreality.

The biggest initiated and implemented action plan of Dutch authorities showed up in 2013 when unemployment rates among young people were very high. ${ }^{9}$ One of institutional solutions was appointing an ambassador for tackling youth unemployment. His task is to coordinate the works of local self-governments and employers to increase the rates of finding jobs by youth. Additionally, the government found funds for various activating programmes fighting against unemployment. Among them there was Startersbeurs (New Job Seekers Fair) - an initiative ensuring experience for new persons looking for a job; Jongerenloket (Youth Helpdesk) - an initiative offering advices on training and job market; School Ex - a programme of incentives for students finishing vocational schools to continue education (within areas with good perspectives of being hired) and increase competitiveness on the job market (Government makes $€ 50$ ). In result of these initiatives the unemployment rate among young Hollanders dropped significantly. However, new challenges showed up, associated with the refugee crisis observed in Europe from 2015. In 2016, after auditing hitherto activities, Netherlands together with the European Commission defined two fundamental challenges for upcoming years. First, was to support migrant youth endangered by

9 There was $12,5 \%$ of unemployed youth born in Netherlands and nearly $25 \%$ born beyond the EU (Eurostat, 2020). 
unemployment ${ }^{10}$ and quick rotation from educational system. Second, it was discerned a necessity to supervise the durability of abilities acquired during employment, education and trainings, to verify the effectiveness of programmes implemented by the state and its institutions (European Commission, 2020, p. 7). Again, it seems that at least in the matter of fighting against unemployment among young migrants Netherlands succeeded. Unemployment rate among youth born beyond the EU dropped from 19,4\% in 2016 to $12,6 \%$ in 2018.

A huge challenge for Dutch authorities in the process of decreasing NEET rate is disability or sickness given as reasons for professional or educational inactivity. The analysis conducted by the Statistics Netherlands shows that more than a half of NEETs indicates sickness or disability as a reason behind their unemployment (CBS, Centraal Bureau voor de Statistiek) (see Chart 3). Although according to the Dutch law companies should hire $2-5 \%$ disabled persons, there is no obligation for doing that (Fighting youth unemployment). At the same time, some experts draw attention to the fact that the Dutch authorities transfer the costs of hiring and keeping disabled workers (or generally sick persons) to employers (Van de Water, 2015). These factors combined with the common benefits for people unable to work may significantly influence the employment rates among sick or disabled persons.

\section{Chart 3. The reasons of unemployment or readiness to work among young Hollanders} (2017)

\section{Reasons of unemployment or the lack of readiness to work (2017)}

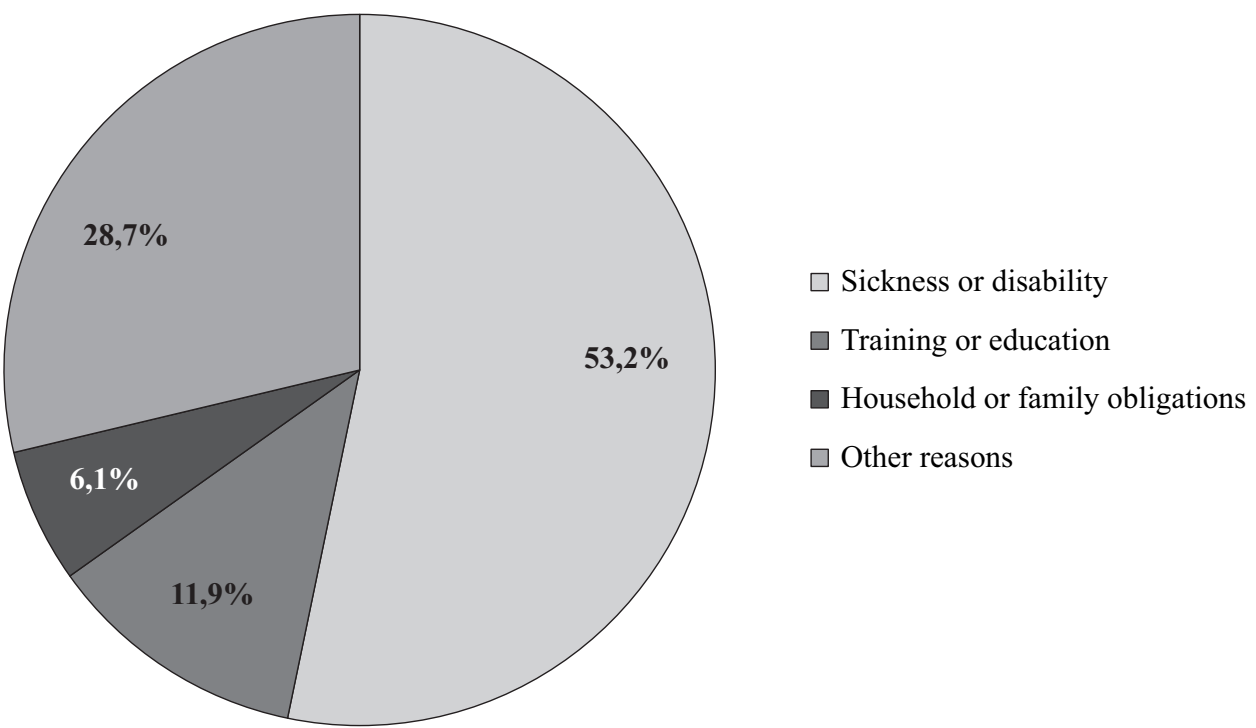

Source: Own study based on CBS, 2018.

${ }^{10}$ In 2016 the unemployment rate among young Hollanders born in Netherlands or in one of the EU countries was $12,9 \%$ while among youth born beyond the EU 19,4\% (the difference of $6,5 \%$ ). Until 2018 the difference was decreased to $0,5 \%(12,1 \%$ vs. 12,6\%). Even bigger differences may be observed comparing the unemployment rate among young people born in Netherlands $(10,4 \%$ in 2016 and 6,8\% in 2018) and those born beyond the EU (19,4\% in 2016 and 12,6\% in 2018) (Eurostat, 2020). 
Slightly more than $6 \%$ persons qualified as NEETs stated that household obligations make continuing education or working impossible. $12 \%$ young Hollanders does not work because of doing additional trainings and courses. There is also a huge group of $29 \%$ of unemployed youth which gave different reasons for its lack of activity on the job market.

Netherlands with its complex solutions remains a leader in counteracting against the increase of NEET rate for over a decade. The typical Dutch representative of NEETs has a low education and is withdrawn from the job market and education system which is why the Dutch authorities undertake numerous initiatives for the activization of young people, assuring them trainings, internships or state support for entering or returning to the job market. In recent years there were discerned several new challenges associated with the problem of young, inactive citizens. Beside quick abandoning the education system by young Dutchmen, presently the Dutch authorities have to face the problem of high unemployment rate among young refugees and the lack of professional and educational activity among sick and disabled persons. Although these areas enjoy already implemented programmes and the first achievements may already be observed, these issues will remain the leading challenges in the nearest future.

\section{Conclusion}

Economic recession from 2008 was mostly experienced by young people. it is worth to pay attention to the fact that when it comes to the unemployment rate, the difference between women and men decreased in the analyzed period. In case of NEET the situation was similar - the indicator's gender disproportions decreased as well.

The increase of young people's chances for being hired is an integral part of ET 2020 framework, ${ }^{11}$ i.e. European cooperation in the areas of training and education. The cooperation was developed to create possibilities for reaching the best practices in education policy, also in terms of gathering and sharing knowledge. It is aimed to support the development of state policies reform at the national and regional level (European Commission, European policy cooperation). To effectively increase the young people's employment chances there was created an employment indicator for people 20-34 years old who successfully accomplished education in last 1-3 years at the master level. It was assumed that its value should not fall beneath $82 \%$. In 2013 its value was $75,4 \%$ while yet in 2018: 81,6\% so not much worse than the ET 2020's aim.

The highest NEET indicator value in history was 17,2\% which happened in 2012 during the world economic crisis. Fortunately, in following years a decreasing tendency dominated. For six another years the indicator value was decreasing up to $13,7 \%$ in 2018. In 2016-2017 there could be observed a decrease of $0,9 \%$ which was the biggest one in the analyzed period. In 2017-2018 its value was $0,6 \%$.

Analyzing the NEETs indicator in European countries, it can be observed that it varies significantly from the low level in Netherland $-4,2 \%$, to Italy which in 2018 reached

${ }^{11}$ More about ET 2020 in 2012 Joint Report of the Council and the Commission on the implementation of the Strategic Framework for European cooperation in education and training (ET 2020), Official Journal of the European Union. 
$19,2 \%$. In 2008 the situation was similar: in Netherlands it was 3,4\%, while in Italy $16,6 \%$. However, in the majority of European countries the trend is decreasing. Exceptions are: Italy, Greece, Denmark, Croatia, Cyprus and Romania in which the indicator value in 2018 was higher than in 2008.

The situation slowly stabilizes, however, the issue requires many activities in different areas. To re-engage young people in education, training and employment, there are needed programmes guaranteeing the possibility of planning a stable future. Considering the negative consequences of premature unemployment and the lack of professional activity, it is of major importance for all NEETs having problems with finding job or an adequate educational offer to actively participatee in programmes aimed to help to overcome barriers to employment. So, to be able to fight against this problem, there is needed a cooperation of both sides: the state as a coordinator and the interested party, i.e. youth as active participants of programmes offered by the states.

A kind of example for other states may be Netherlands which has had the lowest NEET indicator for over a decade. The authorities of that country constantly undertake activities aimed to decrease unemployment among youth and to maintain them in the educational system. Netherlands, as one of the first European countries, faces challenges that are yet to come to other EU member states. Unemployment among refugees, quick finishing education and the lack of professional activity among people with disabilities are not only challenges for today, but also for the next decades.

\section{Bibliography}

Amsterdam uses gamification to fight youth unemployment, Dutch Daily News, https://dutchdailynews. com/amsterdam-uses-gamification-to-fight-youth-unemployment/, 16.04.2020.

Balcerowicz-Szkutnik M., Wąsowicz J. (2017), Pokolenie NEETs na rynku pracy - aktualne problemy, "Studia Ekonomiczne. Zeszyty Naukowe Uniwersytetu Ekonomicznego w Katowicach", no. 312 .

CBS (2018), 4\% of youth not in employment, education or training, https://www.cbs.nl/en-gb/ news/2018/16/4-of-youth-not-in-employment-education-or-training, 16.04.2020.

European Foundation for the Improvement of Living and Working Conditions (2012), NEETs. Young people not in employment, education or training: Characteristics, costs and policy responses in Europe, Luxembourg.

Elder S. (2015), What does NEETs mean and why is the concept so easily misinterpreted, Technical Brief no. 1, International Labour Office, January.

Eurofund (2018), Młode osoby a praca, January 2018.

European Commission (2018), Effective outreach to NEETs. Experience from the ground, Luxembourg.

European Commission (2020), Youth Guarantee country by country. Netherlands, Luxembourg.

European Commission, European policy cooperation (ET 2020 Framework), https://ec.europa.eu/education/policies/european-policy-cooperation/et2020-framework_en, access: 27.01.2020.

European Court of Auditors (2018), Audit Compendium. Youth unemployment and the integration of young people into the labour market, Contact Committee of the Supreme Audit Institutions of the European Union, April 2018.

Europejska Agencja na Rzecz Poprawy Warunków Życia i Pracy, www.eurofound.europa.eu.

Europejska Fundacja na rzecz Poprawy Warunków Życia i Pracy (2017), Młodzi ludzie i młodzież bierna spotecznie (tzw. grupa NEET) w Europie: podstawowe ustalenia, December 2017. 
Eurostat (2020), Unemployment rates by sex, age and country of birth (\%), http://appsso.eurostat. ec.europa.eu/nui/submitViewTableAction.do, 16.04.2020.

Eurostat Statistical Books (2015), Sustainable development in European Union. Key messages, 2015 edition.

Fighting youth unemployment in the Netherlands, https://www.euronews.com/2013/01/25/fightingyouth-unemployment-in-the-netherlands, 16.04.2020.

Government makes $€ 50$ million extra available to fight youth unemployment, Government of the Netherlands, https://www.government.nl/topics/youth-policy/news/2013/03/07/government-makes50-million-extra-available-to-fight-youth-unemployment, 16.04.2020.

Institute for Public Policy Research (2013), No more NEETs. A plan for all young people to be learning or earning, London.

Netherlands: Youth unemployment rate from 1999 to 2019, https://www.statista.com/statistics/812282/ youth-unemployment-rate-in-netherlands/, 15.04.2020.

OECD, (2007), Jobs for youth: Korea, Paris.

OECD (2009), Jobs for youth: Japan, Paris.

OECD (2016), The NEET challenge: What can be done for jobless and disengaged youth?

Official Journal of the European Union, 2012 Joint Report of the Council and the Commission on the implementation of the Strategic Framework for European cooperation in education and training (ET 2020).

Official Journal of the European Union, Regulation (EU) No. 1304/2013 of the European Parliament and of the Council of 17 December 2013 on the European Social Fund and Repealing Council Regulation (EC) No. 1081/2006.

Pyrek R. (2012), Flexicurity - nowa koncepcja rynku pracy, “Zeszyty Naukowe Małopolskiej Wyższej Szkoły Ekonomicznej w Tarnowie”, vol. 20, no. 1.

Skórska A. (2016), Przestrzenne zróżnicowanie sytuacji młodzieży z grupy NEET na rynku pracy Unii Europejskiej, "Studia Ekonomiczne. Zeszyty Naukowe Uniwersytetu Ekonomicznego w Katowicach", no. 289.

Tomczyk Ł., Maćkowicz J., Wyżga O., Curyło-Sikora P., Pietryga-Szkarłat B., Mróz A., Duda A. (2018), NEET - młodzi dorośli poza rynkiem pracy i systemem edukacyjnym, "Edukacja Dorosłych", no. 1.

Van de Water P. N. (2015), 4 Reasons Why the Netherlands Isn't a Model for Disability Insurance, https://www.cbpp.org/blog/4-reasons-why-the-netherlands-isnt-a-model-for-disability-insurance, 16.04.2020.

Youth and employment, Government of the Netherlands, https://www.government.nl/topics/youth-policy/youth-and-employment, 16.04.2020.

Youth unemployment rate in the European Union and the euro area from 2009 to 2019, https://www. statista.com/statistics/253519/youth-unemployment-rate-in-the-european-union-and-the-euroarea/, 15.04.2020.

\section{Analiza sytuacji młodzieży NEET w krajach UE-28 na przykładzie Holandii}

\section{Streszczenie}

Celem artykułu jest zaprezentowanie zróżnicowania wskaźnika NEET wśród państw UE-28 na podstawie najnowszych badań statystycznych Eurostatu. Analiza obejmuje przedział czasowy od roku 2008, jako okresu pokryzysowego, aż do roku 2018. Efektem realizacji celu pracy powinna być odpowiedź na pytanie, jak zmieniła się sytuacja NEETs na przestrzeni dekady. Problem badawczy w niniejszym artykule dotyczy przede wszystkim sytuacji młodych ludzi na rynku pracy UE. W związku 
z utrzymującym się negatywnym trendem wysokiego bezrobocia wśród młodzieży, wydaje się być uzasadnione przeanalizowanie go z perspektywy dziesięcioletniej, która pozwala na bardziej kompleksową ocenę zagadnienia. Analiza zostanie uzupełniona o badanie dotyczące tego, w jaki sposób z problemem radzi sobie Holandia, czyli państwo, które od lat notuje najniższe wskaźniki NEETs i dla wielu innych członków UE pozostaje wzorem do naśladowania.

Słowa kluczowe: generacja NEETs, bezrobocie wśród młodzieży, bezrobocie w Unii Europejskiej, NEETs w Holandii, wspieranie młodzieży na rynku pracy 
